\title{
Organocatalytic asymmetric allylic amination of Morita-Baylis-Hillman carbonates of isatins
}

\author{
Hang Zhang, Shan-Jun Zhang, Qing-Qing Zhou, Lin Dong \\ and Ying-Chun Chen ${ }^{*}$
}

\author{
Letter \\ Address: \\ Key Laboratory of Drug-Targeting and Drug Delivery System of the \\ Education Ministry, Department of Medicinal Chemistry, West China \\ School of Pharmacy, Sichuan University, Chengdu 610041, China \\ Email: \\ Ying-Chun Chen* - ycchenhuaxi@yahoo.com.cn \\ * Corresponding author \\ Keywords: \\ allylic amination; asymmetric organocatalysis; Morita-Baylis-Hillman \\ carbonates; 2-oxindoles; quaternary chiral center
}

Open Access

\author{
Beilstein J. Org. Chem. 2012, 8, 1241-1245. \\ doi:10.3762/bjoc. 8.139 \\ Received: 29 May 2012 \\ Accepted: 09 July 2012 \\ Published: 06 August 2012 \\ This article is part of the Thematic Series "Organocatalysis". \\ Guest Editor: B. List \\ (c) 2012 Zhang et al; licensee Beilstein-Institut. \\ License and terms: see end of document.
}

\begin{abstract}
The investigation of a Lewis base catalyzed asymmetric allylic amination of Morita-Baylis-Hillman carbonates derived from isatins afforded an electrophilic pathway to access multifunctional oxindoles bearing a C3-quaternary stereocenter, provided with good to excellent enantioselectivity (up to $94 \%$ ee) and in high yields (up to 97\%).
\end{abstract}

\section{Introduction}

Chiral 3-amino-2-oxindoles are versatile and useful units for the preparation of natural products and drug candidates, such as the vasopressin VIb receptor antagonist SSR-149415 [1,2], the potent gastrin/CCK-B receptor antagonist AG-041R [3], chartelline $C[4,5]$ and psychotrimine [6]. Therefore, the development of asymmetric protocols to construct such chiral scaffolds has provoked wide interest. The application of 3 -substituted oxindoles as nucleophiles in the reactions with azodicarboxylates or nitrosobenzene provides a very simple and direct approach for the synthesis of optically active 3-amino-2oxindole derivatives [7], either by the catalysis of chiral metal complexes [8-10] or organic catalysts [11-15]. On the other hand, the asymmetric addition to electrophilic imines of isatins is also an attractive pathway, and a variety of examples have been presented [16-21].
Recently, we have developed the asymmetric allylic alkylation reactions [22] with Morita-Baylis-Hillman (MBH) carbonates of isatins to obtain 2-oxindoles bearing a $\mathrm{C} 3$-quaternary chiral center, by the catalysis of chiral tertiary amines, $\beta$-isocupreidine $(\beta$-ICD) or its derivatives [23,24]. We envisaged that such a catalytic strategy should be applicable to the allylic amination of the corresponding MBH carbonates [25-28], as outlined in Scheme 1. Thus, multifunctional chiral 3-amino-2oxindoles could be obtained in a straightforward manner.

\section{Results and Discussion}

Based on the above considerations, we initially investigated the reaction of $\mathrm{MBH}$ carbonate 2a and a diversity of nucleophilic nitrogen sources by the catalysis of DABCO. No desired reaction occurred for phthalimide [25] or $N$-allyl $p$-toluenesulfon- 


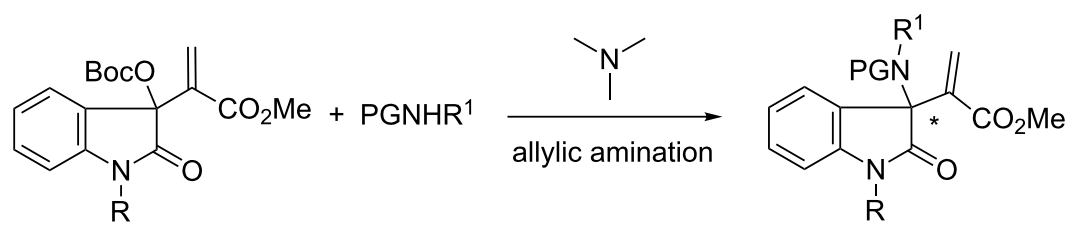

Scheme 1: Allylic amination of MBH carbonates of isatins to access 3-amino-2-oxindoles.

amide [27], which has been successfully applied in the asymmetric amination of MBH carbonates derived from aryl aldehydes. Pleasingly, the reaction took place smoothly to afford product 4a when hydroxylamine 3a with $N$-benzyloxycarbonyl and $O$-benzyl groups [29] was applied in diethyl ether (Table 1, entry 1). Subsequently, an array of tertiary amines derived from quinidine was explored to introduce chirality into the product. While poor enantioselectivity was obtained when $\beta$-iso-

Table 1: Screening studies of asymmetric allylic amination of $\mathrm{MBH}$ carbonate of isatin. ${ }^{\text {a }}$<smiles>C=C(OC(C)=O)C(C)(C(=O)OC)C(=O)N(C)c1ccccc1</smiles>

2a

$$
\begin{aligned}
& \text { 3a } R^{1}=C b z, R^{2}=B n \\
& \text { 3b } R^{1}=B o c, R^{2}=B n \\
& \text { 3c } R^{1}=C b z, R^{2}=T E S \\
& \text { 3d } R^{1}=C b z, R^{2}=\text { TBS } \\
& \text { 3e } R^{1}=C b z, R^{2}=\text { TIPS }
\end{aligned}
$$

$\underset{3}{\mathrm{R}^{1} \mathrm{NHOR}^{2}} \stackrel{\mathbf{1}(10 \mathrm{~mol} \%)}{\underset{\text { solvent, } \mathrm{rt}}{\stackrel{\text { a }}{\longrightarrow}}}$<smiles>[X]c1ccc2nccc(C3OCC4(CC)CCN3C4)c2c1</smiles>

\begin{tabular}{|c|c|c|c|c|c|c|}
\hline entry & 1 & 3 & solvent & $t(\mathrm{~h})$ & yield ${ }^{b}(\%)$ & $\mathrm{ee}^{\mathrm{c}}(\%)$ \\
\hline 1 & $\mathrm{DABCO}$ & $3 a$ & $\mathrm{Et}_{2} \mathrm{O}$ & 12 & $4 a, 86$ & - \\
\hline 2 & $1 a$ & $3 a$ & $\mathrm{Et}_{2} \mathrm{O}$ & 12 & $4 a, 83$ & 17 \\
\hline 3 & $1 \mathrm{~b}$ & $3 a$ & $\mathrm{Et}_{2} \mathrm{O}$ & 12 & $4 a, 80$ & 37 \\
\hline 4 & $1 c$ & $3 a$ & $\mathrm{Et}_{2} \mathrm{O}$ & 12 & $4 a, 85$ & 52 \\
\hline 5 & 1d & $3 a$ & $\mathrm{Et}_{2} \mathrm{O}$ & 12 & $\mathbf{4 a}, 85$ & 58 \\
\hline 6 & $1 d$ & $3 b$ & $\mathrm{Et}_{2} \mathrm{O}$ & 12 & $4 b,<10$ & - \\
\hline 7 & $1 d$ & $3 c$ & $\mathrm{Et}_{2} \mathrm{O}$ & 12 & 4c, 80 & 72 \\
\hline 8 & $1 d$ & $3 d$ & $\mathrm{Et}_{2} \mathrm{O}$ & 24 & $4 d, 85$ & 83 \\
\hline 9 & $1 d$ & $3 e$ & $\mathrm{Et}_{2} \mathrm{O}$ & 12 & $4 e, 53$ & 72 \\
\hline 10 & $1 e$ & $3 d$ & $\mathrm{Et}_{2} \mathrm{O}$ & 24 & $4 d, 88$ & 77 \\
\hline 11 & $1 f$ & $3 d$ & $\mathrm{Et}_{2} \mathrm{O}$ & 24 & $4 d, 78$ & 72 \\
\hline 12 & $1 \mathrm{~g}$ & $3 d$ & $\mathrm{Et}_{2} \mathrm{O}$ & 24 & 4d, 90 & 74 \\
\hline 13 & $1 \mathrm{~h}$ & $3 d$ & $\mathrm{Et}_{2} \mathrm{O}$ & 24 & $4 d, 88$ & 85 \\
\hline 14 & $1 d$ & $3 d$ & DCE & 18 & $4 d, 74$ & 74 \\
\hline 15 & $1 d$ & $3 d$ & $\mathrm{PhCF}_{3}$ & 12 & 4d, 93 & 86 \\
\hline 16 & $1 d$ & $3 d$ & $m$-xylene & 12 & 4d, 97 & 82 \\
\hline 17 & 1d & $3 d$ & $\mathrm{PhF}$ & 12 & $4 d, 83$ & 85 \\
\hline 18 & $1 d$ & $3 d$ & $\mathrm{PhCl}$ & 12 & $4 d, 93$ & 88 \\
\hline $19^{d}$ & $1 \mathrm{~h}$ & $3 d$ & $\mathrm{PhCl}$ & 24 & $4 d, 92$ & 91 \\
\hline
\end{tabular}

1a $X=\mathrm{OH} \quad$ 1e $X=1-N a p h t h y l$

1b $X=O M e \quad$ 1f $X=4-\mathrm{CF}_{3} \mathrm{C}_{6} \mathrm{H}_{4}$

1c $X=O M O M \quad 1 \mathrm{gX}=3,5-\mathrm{Me}_{2} \mathrm{C}_{6} \mathrm{H}_{3}$

$1 \mathrm{~d} X=\mathrm{Ph} \quad 1 \mathrm{~h} X=4-t-\mathrm{BuC}_{6} \mathrm{H}_{4}$

a Unless otherwise noted, reactions were performed with $0.12 \mathrm{mmol}$ of $2 \mathrm{a}, 0.1 \mathrm{mmol}$ of 3 , and $0.01 \mathrm{mmol} 1$ of in $0.5 \mathrm{~mL}$ solvent at room temperature. bIsolated yield. " Based on chiral HPLC analysis. ${ }^{\mathrm{d} A t} 0{ }^{\circ} \mathrm{C}$. 
cupreidine 1a ( $\beta$-ICD) or $\beta$-isoquinidine 1b was used (Table 1 , entries 2 and 3 ), a moderate ee value was attained in the presence of $O$-MOM isocupreidine 1c (Table 1, entry 4) [30]. Moreover, even a slightly higher enantiocontrol was observed for a phenyl-substituted amine 1d (Table 1, entry 5) [31]. Consequently, we paid attention to the structural modifications on the nitrogen source. Very poor conversion was observed when $N$-Boc protected hydroxylamine $\mathbf{3} \mathbf{b}$ was applied in the catalysis by $\mathbf{1 d}$ (Table 1, entry 6). To our gratification, dramatically improved enantioselectivity was obtained for $\mathbf{3 c}$ bearing an $O$-TES group (Table 1, entry 7), and an even higher ee value was gained for $\mathbf{3 d}$ with a bulkier $O$-TBS group, although it exhibited lower reactivity (Table 1 , entry 8 ). Nevertheless, inferior results were afforded for $3 \mathbf{e}$ with an $O$-TIPS group (Table 1, entry 9). Furthermore, we prepared more isocupreidines with diverse aryl-substitutions and tested their catalytic efficacy in the reaction of MBH carbonate $\mathbf{2 a}$ and $\mathbf{3 d}$. Diminished enantioselectivity was delivered in the presence of catalysts 1e-1g (Table 1, entries 10-12), but a slightly higher ee value could be obtained upon catalysis by $\mathbf{1 h}$ with a 4-tertbutylphenyl group (Table 1, entry 13). In addition, a number of solvents were investigated in the catalysis by $\mathbf{1 d}$ (Table 1 , entries 14-18), and chlorobenzene was found to be the optimal selection (Table 1, entry 18). Finally, it was found that the reaction still proceeded smoothly at $0{ }^{\circ} \mathrm{C}$, and a high ee value could be obtained in the catalysis by amine $\mathbf{1 h}$, although a longer reaction time was required to give a better yield (Table 1, entry 19). It should be noted that the reaction became sluggish when $(S)$-BINOL [32] was added, and even no reaction happened in the presence of other additives such as $\mathrm{LiClO}_{4}$ or $\mathrm{Ti}(\mathrm{OiPr})_{4}[33]$.

With the optimized conditions in hand, we explored a diversity of MBH carbonates derived from isatins in the reactions with protected hydroxylamine $\mathbf{3 d}$ by the catalysis of chiral amine $\mathbf{1 h}$ in chlorobenzene at $0{ }^{\circ} \mathrm{C}$. The results are summarized in Table 2. A series of MBH carbonates 2 bearing either electrondonating or -withdrawing substituents on the aromatic moiety of 2-oxindoles were well tolerated. A higher reactivity was generally observed for MBH carbonates with electron-donating substitutions, and excellent yields and enantioselectivity were obtained (Table 2, entries 2-4). On the other hand, MBH carbonates with electron-withdrawing groups exhibited a slower reaction rate, but both good yields and ee values were still obtained (Table 2, entries 5-10).

As outlined in Scheme 2, some synthetic transformations were conducted with the multifunctional allylic amination product 4d. The $\mathrm{N}-\mathrm{O}$ bond cleavage of $\mathbf{4 d}$ could be realized with $\mathrm{Zn}$ powder in acetic acid to produce compound $\mathbf{5}$, albeit in modest yield [34,35], whose absolute configuration has been determined by X-ray analysis [36]. The removal of the $O$-TBS unit proceeded efficiently in the presence of hydrofluoric acid, and an intramolecular transesterification process of intermediate 6 happened to afford a spirocyclic oxindole 7 without loss of enantiopurity [37].

\begin{tabular}{llll}
\hline Table 2: Substrate scope and limitations. ${ }^{a}$ & & \\
\hline & & & \\
\hline
\end{tabular}

aReactions were performed with $0.12 \mathrm{mmol}$ of $2,0.1 \mathrm{mmol}$ of $3 \mathrm{~d}$, and $0.01 \mathrm{mmol}$ of $1 \mathrm{~h}$ in $0.5 \mathrm{~mL}$ of chlorobenzene at $0{ }^{\circ} \mathrm{C}$. ${ }^{\mathrm{b}} / \mathrm{solated}$ yield. ${ }^{\mathrm{C}} \mathrm{Based}$ on chiral HPLC analysis. 

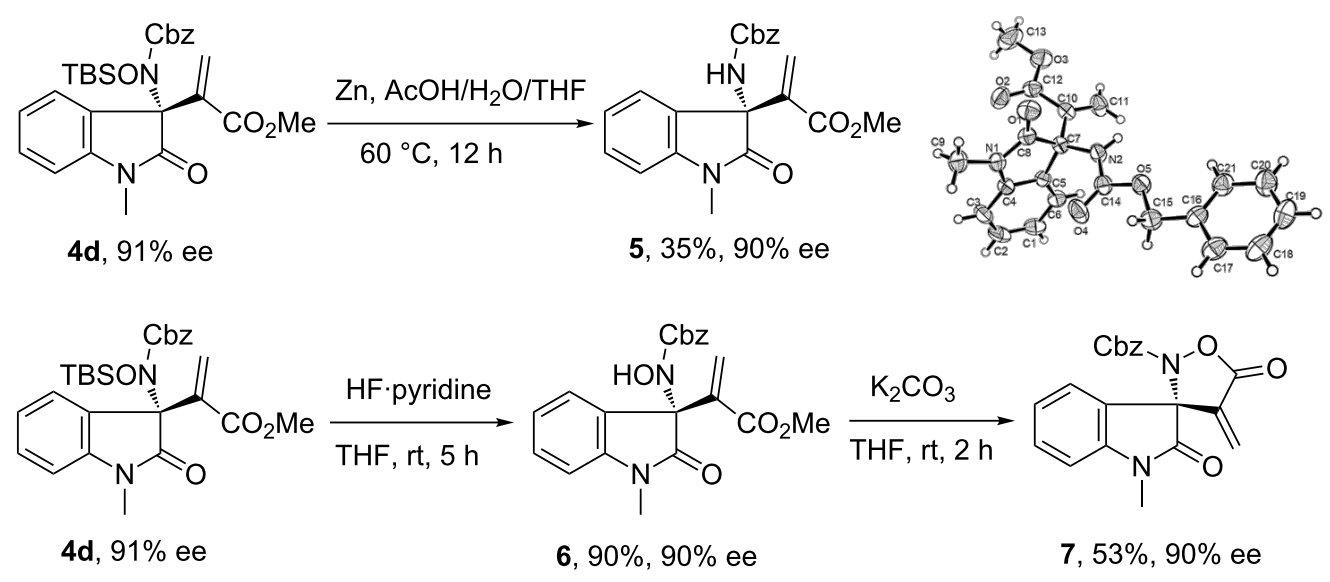

Scheme 2: Synthetic transformations of multifunctional product 4d.

\section{Conclusion}

We have developed a highly enantioselective allylic amination of Morita-Baylis-Hillman carbonates of isatins with $N$-silyloxycarbamates by the catalysis of a modified $\beta$-ICD derivative, which provides an electrophilic process to 3-amino2-oxindoles with a C3-quaternary chiral center. A range of products with high molecular complexity were obtained with good to excellent enantioselectivity (up to $94 \%$ ee) and high yields (up to 97\%). Currently, more studies on the catalytic asymmetric transformations of $\mathrm{MBH}$ carbonates of isatins are under way in our laboratory.

\section{Supporting Information}

General experimental procedures, copies of ${ }^{1} \mathrm{H},{ }^{13} \mathrm{C}$ NMR spectra and HPLC chromatograms for all new compounds, crystal data and structure refinement for enantiopure $\mathbf{5}$.

\section{Supporting Information File 1}

General procedures and analytical data.

[http://www.beilstein-journals.org/bjoc/content/

supplementary/1860-5397-8-139-S1.pdf]

\section{Acknowledgements}

We are grateful for the financial support from the NSFC (grant no. 21125206 and 21021001).

\section{References}

1. Bernard, K.; Bogliolo, S.; Ehrenfeld, J. Br. J. Pharmacol. 2005, 144, 1037-1050. doi:10.1038/sj.bjp.0706103

2. Serradeil-Le Gal, C.; Derick, S.; Brossard, G.; Manning, M.; Simiand, J.; Gaillard, R.; Griebel, G.; Guillon, G. Stress 2003, 6, 199-206. doi:10.1080/1025389032000114524
3. Ochi, M.; Kawasaki, K.; Kataoka, H.; Uchio, Y.; Nishi, H. Biochem. Biophys. Res. Commun. 2001, 283, 1118-1123. doi:10.1006/bbrc.2001.4911

4. Chevolot, L.; Chevolot, A. M.; Gajhede, M.; Larsen, C.; Anthoni, U.; Christophersen, C. J. Am. Chem. Soc. 1985, 107, 4542-4543. doi:10.1021/ja00301a027

5. Anthoni, U.; Chevolot, L.; Larsen, C.; Nielsen, P. H.; Christophersen, C. J. Org. Chem. 1987, 52, 4709-4712. doi:10.1021/jo00230a010

6. Takayama, H.; Mori, I.; Kitajima, M.; Aimi, N.; Lajis, N. H. Org. Lett. 2004, 6, 2945-2948. doi:10.1021/ol048971x

7. Shen, K.; Liu, X.; Lin, L.; Feng, X. Chem. Sci. 2012, 3, 327-334. doi:10.1039/c1sc00544h

8. Mouri, S.; Chen, Z.; Mitsunuma, H.; Furutachi, M.; Matsunaga, S.; Shibasaki, M. J. Am. Chem. Soc. 2010, 132, 1255-1257. doi:10.1021/ja908906n

9. Yang, Z.; Wang, Z.; Bai, S.; Shen, K.; Chen, D.; Liu, X.; Lin, L.; Feng, X. M. Chem.-Eur. J. 2010, 16, 6632-6637. doi:10.1002/chem.201000126

10. Shen, K.; Liu, X.; Wang, G.; Lin, L.; Feng, X. Angew. Chem., Int. Ed. 2011, 50, 4684-4688. doi:10.1002/anie.201100758

11. Cheng, L.; Liu, L.; Wang, D.; Chen, Y.-J. Org. Lett. 2009, 11, 3874-3877. doi:10.1021/ol901405r

12. Zhou, F.; Ding, M.; Liu, Y.-L.; Wang, C.-H.; Ji, C.-B.; Zhang, Y.-Y.; Zhou, J. Adv. Synth. Catal. 2011, 353, 2945-2952. doi:10.1002/adsc.201100379

13. Bui, T.; Hernández Torres, G.; Milite, C.; Barbas, C. F., III. Org. Lett. 2010, 12, 5696-5699. doi:10.1021/ol102493q

14. Bui, T.; Borregan, M.; Barbas, C. F., III. J. Org. Chem. 2009, 74, 8935-8938. doi:10.1021/jo902039a

15. Qian, Z.-Q.; Zhou, F.; Du, T.-P.; Wang, B.-L.; Ding, M.; Zhao, X.-L.; Zhou, J. Chem. Commun. 2009, 6753-6755. doi:10.1039/b915257a

16. Lesma, G.; Landoni, N.; Pilati, T.; Sacchetti, A.; Silvani, A. J. Org. Chem. 2009, 74, 4537-4541. doi:10.1021/jo900623c

17. Jung, H. H.; Buesking, A. W.; Ellman, J. A. Org. Lett. 2011, 13, 3912-3915. doi:10.1021/ol201438k

18. Cao, Z.-Y.; Zhang, Y.; Ji, C.-B.; Zhou, J. Org. Lett. 2011, 13, 6398-6401. doi:10.1021/ol202705g

19. Guo, Q.-X.; Liu, Y.-W.; Li, X.-C.; Zhong, L.-Z.; Peng, Y.-G. J. Org. Chem. 2012, 77, 3589-3594. doi:10.1021/jo202585w 
20. Yan, W.; Wang, D.; Feng, J.; Li, P.; Wang, R. J. Org. Chem. 2012, 77, 3311-3317. doi:10.1021/jo300110a

21. Yan, W.; Wang, D.; Feng, J.; Li, P.; Zhao, D.; Wang, R. Org. Lett. 2012, 14, 2512-2515. doi:10.1021/ol3007953

22. Liu, T.-Y.; Xie, M.; Chen, Y.-C. Chem. Soc. Rev. 2012, 41, 4101-4112. doi:10.1039/c2cs35017c

23. Peng, J.; Huang, X.; Cui, H.-L.; Chen, Y.- C. Org. Lett. 2010, 12, 4260-4263. doi:10.1021/ol101668z

24. Huang, X.; Peng, J.; Dong, L.; Chen, Y.-C. Chem. Commun. 2012, 48, 2439-2441. doi:10.1039/c2cc17777c

25. Zhang, S.-J.; Cui, H.-L.; Jiang, K.; Li, R.; Ding, Z.-Y.; Chen, Y.-C. Eur. J. Org. Chem. 2009, 5804-5809. doi:10.1002/ejoc.200900944

26. Lin, A.; Mao, H.; Zhu, X.; Ge, H.; Tan, R.; Zhu, C.; Cheng, Y. Chem.-Eur. J. 2011, 17, 13676-13679. doi:10.1002/chem.201102522

27. Sun, W.; Ma, X.; Hong, L.; Wang, R. J. Org. Chem. 2011, 76, 7826-7833. doi:10.1021/jo2011522

28. Pei, C.-K.; Zhang, X.-C.; Shi, M. Eur. J. Org. Chem. 2011, 4479-4484. doi:10.1002/ejoc.201100501

29. Chen, Y. K.; Yoshida, M.; MacMillan, D. W. C. J. Am. Chem. Soc. 2006, 128, 9328-9329. doi:10.1021/ja063267s

30. Peng, J.; Huang, X.; Jiang, L.; Cui, H.-L.; Chen, Y.-C. Org. Lett. 2011, 13, 4584-4587. doi:10.1021/ol201776h

31. Waldmann, H.; Khedkar, V.; Dückert, H.; Schürmann, M.; Oppel, I. M.; Kumar, K. Angew. Chem., Int. Ed. 2008, 47, 6869-6872. doi:10.1002/anie.200802413

32. Cui, H.-L.; Peng, J.; Feng, X.; Du, W.; Jiang, K.; Chen, Y.-C. Chem.-Eur. J. 2009, 15, 1574-1577. doi:10.1002/chem.200802534

33. Furukawa, T.; Kawazoe, J.; Zhang, W.; Nishimine, T.; Tokunaga, E.; Matsumoto, T.; Shiro, M.; Shibata, N. Angew. Chem., Int. Ed. 2011, 50, 9684-9688. doi:10.1002/anie.201103748

34. Hu, Z. K.; Cui, H. L.; Jiang, K.; Chen, Y. C. Sci. China, Ser. B: Chem. 2009, 52, 1309-1313. doi:10.1007/s11426-009-0187-8

35. Bentley, S. A.; Davies, S. G.; Lee, J. A.; Roberts, P. M.; Russell, A. J.; Thomson, J. E.; Toms, S. M. Tetrahedron 2010, 66, 4604-4620. doi:10.1016/j.tet.2010.04.027

36. CCDC-888767 (5) contains the supplementary crystallographic data for this paper. These data can be obtained free of charge from The Cambridge Crystallographic Data Centre via http://www.ccdc.cam.ac.uk/data_request/cif. The absolute configuration of chiral products 4 in Table 2 could be assigned accordingly.

37. Benfatti, F.; Cardillo, G.; Contaldi, S.; Gentilucci, L.; Mosconi, E.; Tolomelli, A.; Juaristi, E.; Reyes-Rangel, G. Tetrahedron 2009, 65, 2478-2483. doi:10.1016/j.tet.2009.01.071

\section{License and Terms}

This is an Open Access article under the terms of the Creative Commons Attribution License

(http://creativecommons.org/licenses/by/2.0), which permits unrestricted use, distribution, and reproduction in any medium, provided the original work is properly cited.

The license is subject to the Beilstein Journal of Organic Chemistry terms and conditions:

(http://www.beilstein-journals.org/bjoc)

The definitive version of this article is the electronic one which can be found at:

doi:10.3762/bjoc. 8.139 